[This is the pre-peer reviewed version of the following article: 'The meaning of Hendon: the Royal Air Force Display, aerial theatre and the technological sublime, 1920-37', which has been accepted for publication in Historical Research]

\title{
The meaning of Hendon: the Royal Air Force Display, aerial theatre and the technological sublime, 1920-37
}

Brett Holman

University of Canberra; University of New England

bholman@airminded.org

https: / / airminded.org

\section{Acknowledgements}

For their advice and assistance, the author would like to thank the following: Peter Hobbins, Thomas Kehoe, James Kightly, Ross Mahoney, Cathy Schapper and Dorthe Gert Simonsen. Part of this research was supported by University of New England Research Seed Grant 19261.

\section{Introduction}

It is 2 July 1927. Two squadrons of hostile bombers approach London, preparing to unload their deadly cargo on the great metropolis. Fortunately, they are intercepted by two British fighter squadrons, which manage to destroy or turn back the enemy aircraft, albeit at terrible cost to themselves. Shortly afterwards, in a far-flung corner of empire, the European residents of a small village come under attack from their indigenous neighbours. Their distress signals are seen by a British aerial patrol, which radios for assistance. As the colonists withdraw under fire across a bridge, a friendly bomber squadron arrives and targets the hostile insurgents. Three large transport aircraft land nearby and take the white refugees to safety, as the village burns furiously.

These battles never happened. Or, rather, they only happened as entertainment, as the spectacular climax to a highly-choreographed and heavily-publicised performance of British airpower: the Royal Air Force (RAF) 
Display, held annually at Hendon aerodrome in north London between 1920 and 1937, to shape the public image of Britain's newest arm of defence. ${ }^{1}$ One day every summer (weather permitting) dozens of military aircraft soared and dived over Hendon, looped and tumbled, flew in formation and fought in mock battles, before huge, enraptured crowds. Attendance at Hendon-as the Display was familiarly known-regularly exceeded 100,000. While the working and middle classes came in droves-the former by bus or Tube, the latter, increasingly, in their motor-cars-the event also came to take a place 'amongst the foremost of the functions of the London social season', with British and foreign royalty in regular attendance, along with political, social, industrial and military elites. ${ }^{2}$ As publicity, Hendon was hugely successful, making the RAF the most visible branch of the armed forces in interwar Britain. As Peter Adey argues, Hendon was one of the 'key meeting posts for the promulgation of flight's message, the performance of a political community and the projection of the nation into the $\mathrm{sky}^{\prime}{ }^{3}$

Just what was being promulgated, performed and projected at Hendonwhat Hendon meant-has long seemed clear. Following David E. Omissi, the Display has overwhelmingly been interpreted by scholars as 'a manifestation of popular imperialism', achieving considerable notoriety for the surprisingly frank portrayal in its climactic set-pieces of Britain's aerial bombardment of its colonial subjects. ${ }^{4}$ These mock battles performed for a metropolitan audience the air control strategies the RAF was actually using to subdue resistance by colonial subjects in Iraq, the North-West Frontier, and elsewhere. Martin Francis, for example, characterises the Hendon set-pieces of the 1920s as 'tasteless and xenophobic', comprising 'mock aerial attacks on "native villages"', while Patrick Deer argues that 'the imperial romance with air power died hard':

In the Hendon Air Pageant, the Air Force targeted a willing metropolitan audience with the pre-emptive displays of air power it had tested in the colonies. The set-pieces were, as David Omissi has pointed out, full of imperial themes and racial coding [...] as late as 1936, the 'set-piece' theme involved the bombing of 'savages', though the airmen playing them were now forbidden from blacking their faces. ${ }^{5}$

\footnotetext{
${ }^{1}$ The only detailed studies of the RAF Display are David E. Omissi, 'The Hendon Air Pageant, 1920-1937', in John M. MacKenzie (ed.), Popular Imperialism and the Military (Manchester: Manchester University Press, 1992), 198-220; David Oliver, Hendon Aerodrome: A History (Shrewsbury: Airlife, 1994); see also Peter Adey, Aerial Life: Spaces, Mobilities, Affects (Chichester: Wiley-Blackwell, 2010), 57-64.

${ }^{2}$ Flight, 8 July 1926, 399.

${ }^{3}$ Adey, Aerial Life, 57.

${ }^{4}$ Omissi, 'The Hendon Air Pageant', 199.

${ }^{5}$ Martin Francis, The Flyer: British Culture and the Royal Air Force, 1939-1945 (Oxford: Oxford University Press, 2008), 17; Patrick Deer, Culture in Camouflage: War, Empire, and Modern British Literature (Oxford: Oxford University Press, 2009), 66.
} 
Paul K. Saint-Amour asks, 'why did the [RAF's] public spectacles during the 1920s insist so outlandishly on the whiteness of the bomber, the blackness of the bombed?'6

The answer to Saint-Amour's question must be that while the RAF's spectacles did insist on the whiteness of the bomber, they did not, in fact, insist on the blackness of the bombed. While nakedly imperialistic visual rhetoric was certainly used at Hendon, it was far from the only or even the dominant kind: of the sixteen set-pieces performed or planned across the history of the Display, only four were set in clearly imperial contexts. Instead, most portrayed industrialised, and so presumptively European, settings: aerodromes, ports, factories or ships. These kinds of targets need to be seen as the RAF proclaiming its ability to fight and win wars independently, that is, without the aid of the British Army or the Royal Navy. Hendon needs to be reevaluated. It was a cultural projection of what David Edgerton terms liberal militarism: Britain's reliance on technology and industry as the basis of its military power, rather than conscription. ${ }^{7}$

That the RAF was in fact used against indigenous victims in the interwar period simply underlines its value to the British warfare state, reliant upon the ability to project force around the world. Independent, or strategic, airpower was widely believed to be a flexible and relatively cheap weapon, able to defend against threats in the far reaches of empire as well as from across the English Channel or the North Sea, without returning to the costly trench warfare of the First World War or large-scale punitive expeditions on the imperial frontier. However, this potentially immense power was mostly oriented, in theory if not always in practice, against other European powers. While the RAF was never as wedded to the strategic bomber as has often been claimed, revolutionary claims for independent airpower were politically useful in Whitehall's budgetary battles. ${ }^{8}$ Air control helped defend the RAF against threats of dismemberment by the older services, but it did not justify its expansion. Only threats from the Continent could do that, as with France

\footnotetext{
${ }^{6}$ Paul K. Saint-Amour, 'On the partiality of total war', Critical Inquiry 40, no. 2 (2014): 420-449, at 444; see also Paul K. Saint-Amour, Tense Future: Modernism, Total War, Encyclopedic Form (Oxford: Oxford University Press, 2015), 76-80. For other examples, see Sven Lindqvist, A History of Bombing (London: Granta, 2002), before 134; Priya Satia, 'The defense of inhumanity: air control and the British idea of Arabia', American Historical Review 111, no. 1 (2006): 16-51, at 42 fn 115; Bernhard Rieger, Technology and the Culture of Modernity in Britain and Germany, 1890-1945 (Cambridge: Cambridge University Press, 2005), 233; Adey, Aerial Life, 59; Brett Holman, 'The air panic of 1935: British press opinion between disarmament and rearmament', Journal of Contemporary History 46, no. 2 (2011): 288-307, at 293.

${ }^{7}$ David Edgerton, 'Liberal militarism and the British state', New Left Review 185 (1991): 138-169.

${ }^{8}$ John Ferris, 'Fighter defence before Fighter Command: the rise of strategic air defence in Great Britain, 1917-1934', Journal of Military History 63, no. 4 (1999): 845884; Neville Parton, 'The Evolution and Impact of Royal Air Force Doctrine: 19191939', PhD thesis, University of Cambridge (2009), 231.
} 
in 1922 and Germany from 1934 onwards. ${ }^{9}$

Debates about the effective use of airpower were not isolated, but took place within a wider cultural context. The 1920s and 1930s were, as SaintAmour argues, already 'an interwar era whose terminus in global conflict seemed, to many, foreordained', when 'the memory of one world war was already joined to the specter of a second, future one', in which the home front would, paradoxically, become the front line. ${ }^{10}$ This message was promoted by civilian writers: journalists, novelists, pacifists, and military intellectuals, but the British state, too, was both responding and contributing to the existence of this fear of a knock-out blow from the air. ${ }^{11}$ Drawn from the experience of air raids on London in the First World War and naive extrapolations of the advance of aeronautical technology, in this understanding the next war would be fought through mutually devastating air raids on the national economies of the opposing powers:

Imagine for a moment London, Manchester, Birmingham, and half a dozen other great centres simultaneously attacked, the business localities and Fleet Street wrecked, Whitehall a heap of ruins, the slum districts maddened into the impulse to break loose and maraud, the railways cut, factories destroyed. Would not the general will to resist vanish, and what use would be the still determined fraction of the nation, without organization and central direction? ${ }^{12}$

Despite the famous 1932 dictum of Stanley Baldwin, a former and future prime minister, that 'the bomber will always get through [...] The only defence is in offence, which means that you have got to kill more women and children more quickly than the enemy if you want to save yourselves', whether British airpower was itself oriented against civilians was more ambiguous. ${ }^{13}$ Given Britain's proclaimed commitment and moral norms and international law, the RAF could not openly confess to planning to bomb civilians in wartime. Indeed, its own doctrine prohibited it from doing so; but

${ }^{9}$ John Ferris, "The theory of a "French air menace", Anglo-French relations and the British Home Defence Air Force programmes of 1921-25', Journal of Strategic Studies 10, no. 1 (1987): 62-83; Holman, 'The air panic of 1935'.

${ }^{10}$ Saint-Amour, Tense Future, 8 (emphasis in original).

${ }^{11}$ Brett Holman, The Next War in the Air: Britain's Fear of the Bomber, 1908-1941 (Abingdon: Routledge, 2016), 39-50. See also Uri Bialer, The Shadow of the Bomber: The Fear of Air Attack and British Politics, 1932-1939 (London: Royal Historical Society, 1980); Susan R. Grayzel, At Home and Under Fire: Air Raids and Culture in Britain From the Great War to the Blitz (New York: Cambridge University Press, 2012); Michele Haapamaki, The Coming of the Aerial War: Culture and the Fear of Airborne Attack in Inter-War Britain (London: I.B. Tauris, 2014).

${ }^{12}$ B.H. Liddell Hart, Paris, or the Future of War (London: Kegan Paul, Trench, Trubner \& Co., 1925), 47.

${ }^{13}$ Stanley Baldwin, speech, 10 November 1932, Parliamentary Debates, Commons, vol. 270, col. 632, https:/ / api.parliament.uk/ historic-

hansard/commons / 1932/nov/10/international-affairs, accessed 18 February 2019. 
it also relied on a conflation of the 'moral' effect of bombing and its 'physical' effect, emphasising the former without admitting that it needed the latter to be effective. ${ }^{14}$ At Hendon, civilians were rarely shown, in contrast to combatant airmen, soldiers, sailors or 'native' warriors. For the RAF, bombing civilians was almost unrepresentable.

But that does not mean it was unseeable. Hendon's propaganda on behalf of the warfare state was effective because it tapped into a tremendous and widespread fascination with flying, or airmindedness. As a revolutionary new technology, the aeroplane was perhaps the single most recognisable symbol of modernity in the early twentieth century, and its almost mythological ability to defy gravity and transcend distance evoked tremendous feelings of awe. ${ }^{15}$ The attraction of such a technological sublime has been widely analysed in the American context, but is less commonly discussed in relation to British history. ${ }^{16}$ Yet it is readily adaptable to understanding the rhetoric around the Display, which constantly expressed wonder at the spectacle being performed in the sky above Hendon. The RAF relied on these images to publicly affirm its status as an inherently modern arm of defence. Crucially, the awe inspired by the technological sublime encompasses feelings of fear and terror as well as hope and joy, making it an apt concept for understanding the dual nature of the airminded future. ${ }^{17}$ This helps to explain why such a militaristic display was so popular at a time when pacifism was supposed to have been at its height. ${ }^{18}$ After the horror of the First World War, the aeroplane stood for both progress and destruction: a brighter future or a descent into barbarism. ${ }^{19}$ The RAF could hardly avoid the negative aspects of aviation at Hendon, though it did try to stress more positive ones. It could not prevent spectators from reading their own meanings into what they were seeing.

The misreading of Hendon is symptomatic of a larger failure to address the

${ }^{14}$ Tami Davis Biddle, Rhetoric and Reality in Strategic Air Warfare: The Evolution and Reality of British and American Ideas About Strategic Bombing, 1914-1945 (Princeton: Princeton University Press, 2002), 71-73; Richard Overy, The Bombing War: Europe 1939-1945 (London: Allen Lane, 2013), 47-48.

${ }^{15}$ Stephen Kern, The Culture of Time and Space 1880-1918 (Cambridge: Harvard University Press, 1983), 242-247; Dorthe Gert Simonsen, 'Accelerating modernity: time-space compression in the wake of the aeroplane', Journal of Transport History 26, no. 2 (2012): 98-117.

${ }^{16}$ David E. Nye, American Technological Sublime (Cambridge, MA: MIT Press, 1996).

${ }^{17}$ Brenton J. Malin, Feeling Mediated: A History of Media Technology and Emotion in America (New York: NYU Press, 2014), 32. See also Rieger, Technology and the Culture of Modernity.

${ }^{18}$ Daniel Hucker, Public Opinion and the End of Appeasement in Britain and France (Farnham: Ashgate, 2011), 15-16.

${ }^{19}$ Waqar H. Zaidi, "“Aviation will either destroy or save our civilization”: proposals for the international control of aviation, 1920-45', Journal of Contemporary History 46 (2011): 150-178; Peter J. Bowler, A History of the Future: Prophets of Progress from H.G. Wells to Isaac Asimov (Cambridge: Cambridge University Press, 2017), 107-127, 156161. 
emotional - as opposed to military or industrial, or even culturalsignificance of aviation in Britain in the early twentieth century. Unlike the motor car, its nearest rival as a symbol of modernity, the aeroplane was rarely encountered directly, as few people actually flew before the Second World War. It was far more common to experience aviation as entertainment, as an aerial theatre. ${ }^{20}$ Aerial theatre is defined here as the spectacular use of aircraftaeroplanes, airships, balloons - in flight to draw and entertain an audience. These might be commercial events or official ones; they could be highly choreographed, or spontaneous, even unintentional; they could involve large numbers of aircraft, or only one; they might be highly militarised, or wholly pacific. Aerial theatre was hugely popular, often seen by tens and even hundreds of thousands of people at a time who were thereby collectively exposed to an impressive and powerful airminded propaganda. These spectators responded to what they saw in ways familiar from other forms of spectacular entertainment like spectator sports or the cinema: that is to say, emotionally. In contrast to the airborne gaze of the elite pilot, implicitly omniscient and omnipotent, this affective view from below enables us to understand how the masses encountered aviation: both hopefully and fearfully; entertained by it, or bored; above all, engaged, and hence receptive. As Adey suggests, 'The sight of the aeroplane is just as significant as the view from it'. ${ }^{21}$

This article will outline the potential of aerial theatre as an interpretative framework for understanding the affective importance of aviation, and then apply it to the example of the RAF Display at Hendon. It will show that Hendon's set-pieces cannot be read as solely or even primarily imperial in focus, since this was only a minor theme over its history; and that instead, the Display should be seen as a representation of the potential of the RAF to fight and win Britain's wars independently of the Army and the Navy. It will then demonstrate the power of the technological sublime in interwar Britain through analysing how spectators responded emotionally to the spectacles at Hendon, reading into them their own mounting anxieties about aerial bombardment. Rather than being an episode in the promotion of popular imperialism, then, this article will argue that the meaning of Hendon was that the RAF would be able to fight the next war by itself and, ultimately, to win it; but also that the public did not always find this reassuring.

\section{Airmindedness and aerial theatre}

\footnotetext{
${ }^{20}$ Brett Holman, 'The militarisation of aerial theatre: air displays and airmindedness in Britain and Australia between the World Wars." Contemporary British History, advance access, DOI: 10.1080/13619462.2018.1519430.

${ }^{21}$ Adey, Aerial Life, 10. See also Caren Kaplan, Aerial Aftermaths: Wartime From Above

(Durham: Duke University Press, 2018), 102.
} 
Hendon had been the site of civilian air displays in the early days of flying before 1914, where crowds came to see pioneer aviator Claude GrahameWhite loop the loop or, more pointedly, drop flour bombs on the painted outlines of a battleship.22 The RAF, a new arm of national defence formed as a wartime exigency in 1918, traded on this association by taking over the Hendon aerodrome and using it to project a positive image of its capabilities and its work to the British public, at a time when its institutional survival as an independent air force was in doubt. ${ }^{23}$ The inaugural RAF Aerial Pageant was held at Hendon in 1920; from 1925 it was renamed the RAF Display. The programmes were planned by the Air Defence of Great Britain command, under the general oversight of the Air Ministry, and varied from year to year. They consisted of a variety of aerial performances: precision flying, aerial refuelling, simulated bombing or air-to-air combat, and more light-hearted acts such as so-called crazy flying or 'Martian' hunts, all performed, despite the high levels of skill involved, by regular or even reserve aircrews rather than specialist aerobatic teams. Nearly every Display climaxed in a set-piece which simulated a small-scale but complex battle, highlighting various aspects of airpower within the context of a fictional scenario. Considerable effort was put into devising these impressive spectacles, usually involving multiple squadrons of fighters and bombers, and the destruction of fake buildings or ships - even if they were built from discarded aeroplane wings or parachute silk. The first Hendon attracted at least 40,000 ticket-holders; the last (and largest), 195,000, probably the largest crowd for any single-day outdoor event in interwar Britain, eclipsing even hugely popular sporting events like Royal Ascot or the FA Cup. ${ }^{24}$ Even before taking newspapers, newsreels and wireless broadcasts into account, these numbers hardly reflect the true number of spectators: in 1931, for example, while 169,000 ticketholders crammed into the aerodrome itself, benefitting from close-up views and loudspeaker explanations of what they were seeing, perhaps 300,000 or more watched for free from the fields outside. ${ }^{25}$ The sky was the RAF's stage; Hendon, an aerial theatre.

Hendon was not an isolated example of enthusiasm for aviation. In the early twentieth century, the aeroplane was an almost unprecedentedly powerful symbol of both myth and modernity. In turning ancient mythological and cultural dreams of flight into reality, it ruptured the present

${ }^{22}$ Oliver, Hendon Aerodrome, 17-30.

${ }^{23}$ Richard Overy, The Birth of the RAF, 1918: The World's First Air Force (London: Allen Lane, 2018).

${ }^{24}$ Flight, 30 June 1927, 431; Illustrated London News, 3 July 1937, 1 (all newspapers published in London, unless otherwise obvious). This figure is significantly larger than the usually quoted maximum of 169,000 in 1931: Omissi, 'The Hendon Air Pageant', 209. See also Mike Huggins and Jack Williams, Sport and the English, 19181939 (Abingdon: Routledge, 2006), 12-14.

${ }^{25}$ Flight, 27 July 1935, 727. 
from the past as well as, seemingly, the future. ${ }^{26}$ The first practical aeroplane and airship flights at the turn of the 20th century generated a tremendous popular interest in the potential of aviation to change the world. This 'airmindedness', as it was being termed by the late 1920s, was a fundamentally forward-looking mentality, variously predicting that aviation would bring unlimited personal mobility, the end of borders, worldwide democracy or universal destruction. To be airminded was to look towards this aerial future, to anticipate its benefits and guard against its dangers, and to want to share this enthusiasm with other individuals and with society as a whole. ${ }^{27}$

Most studies of airmindedness interpret it as an intellectual and cultural phenomenon. This approach has reaped great rewards in allowing us to understand how the coming of flight affected literature, cinema and art. But it fails to capture an essential part of airmindedness as a popular phenomenon, which was much more visceral than rational, more exciting and thrilling. Airmindedness was, in large part, an emotional experience, an awed response to an incredible sensation..$^{28}$ In other words, it was a rhetoric of the technological sublime. This rhetoric was originally identified by Leo Marx in the context of the early United States, especially in relation to the spread of the railway across the North American continent, seen simultaneously as a cause, a symptom, and a symbol of technological progress. ${ }^{29}$ Later historians have detected this sense of wonder with respect to other new technologies,

\footnotetext{
${ }^{26}$ Robert Wohl, A Passion for Wings: Aviation and the Western Imagination, 1908-1918 (New Haven: Yale University Press, 1994); Robert Wohl, The Spectacle of Flight: Aviation and the Western Imagination, 1920-1950 (Carlton: Melbourne University Press, 2005); Bayla Singer, Like Sex with Gods: An Unorthodox History of Flying (College Station: Texas A\&M University Press, 2003); Fernando Esposito, Fascism, Aviation and Mythical Modernity (Basingstoke: Palgrave Macmillan, 2015), 311-312.

27 Joseph J. Corn, The Winged Gospel: America's Romance with Aviation, 1900-1950 (New York: Oxford University Press, 1983); Peter Fritzsche, A Nation of Fliers: German Aviation and the Popular Imagination (Cambridge (MA): Harvard University Press, 1992); Leigh Edmonds, 'How Australians were made airminded', Continuum 7, no. 1 (1993): 183-206; Scott W. Palmer, Dictatorship of the Air: Aviation Culture and the Fate of Modern Russia (New York: Cambridge University Press, 2006); Gordon Pirie, 'British air shows in South Africa, 1932/33: 'airmindedness', ambition and anxiety', Kronos: Southern African Histories, no. 35 (2009): 48-70; David Edgerton, England and the Aeroplane: Militarism, Modernity and Machines (London: Penguin, 2013); Jürgen Melzer, "We must learn from Germany": gliders and model airplanes as tools for Japan's mass mobilization', Contemporary Japan 26, no. 1 (2014): 1-28.

${ }^{28}$ Liz Millward, Women in British Imperial Airspace, 1922-1937 (Montreal: McGillQueen's University Press, 2008), 29; Peter Adey, "“Ten thousand lads with shining eyes are dreaming and their dreams are wings": affect, airmindedness and the birth of the aerial subject', Cultural Geographies 18, no. 1 (2011): 63-89, at 66; Matthew F. Rech, "A critical geopolitics of observant practice at British military airshows', Transactions of the Institute of British Geographers 40, no. 4 (2015): 536-548, at 537. ${ }^{29}$ Leo Marx, The Machine in the Garden: Technology and the Pastoral Ideal in America (New York: Oxford University Press, 2000).
} 
including the aeroplane. ${ }^{30} \mathrm{~A}$ similar rhetoric has less often been looked for in Britain, but it fits British airmindedness very well, especially when Brenton J. Malin's injunction to include within technological sublimity feelings of fear and terror, as well as hope and joy, is recalled. Particularly in Britain, the aeroplane was identified with the threat of a knock-out blow from the air, and evoked just this kind of perversely 'delightful horror'. ${ }^{31}$

Ideally, airmindedness was generated through the experience of flying itself, whether as a pilot or a passenger. But although in the first few decades of the twentieth century many people took joy flights, before the massive growth of aviation during and after the Second World War it was nevertheless always far more common to see an aeroplane flying than to actually fly in one. ${ }^{32}$ As Liz Millward argues, 'Airmindedness could not just circulate through stories and magazine articles but needed aeroplanes, airfields, and events where people could see aeroplanes and pilots in flight'. ${ }^{33}$ To a much greater extent than has been recognised, airmindedness was created and sustained by the affect of watching flying from the ground: that is, through the excitement of aviation spectacle, as part of an aerial theatre. ${ }^{34}$

Spectacle has a long history, but it is often identified as peculiarly inherent in a modern, capitalist, commodity culture, exemplified by the vast array of commercial products on display at the Great Exhibition of $1851 . .^{35}$ Victorian theatre helped audiences to develop a popular taste for the sensational, and representational forms of consumer spectacle such as panoramas and,

${ }^{30}$ Nye, American Technological Sublime. For example, see Douglas B. Craig, 'Radio, modern communication media and the technological sublime', Radio Journal:

International Studies in Broadcast \& Audio Media 6, no. 2 (2008): 129-143; James W. Carey, 'Historical pragmatism and the internet', New Media E Society 7, no. 4 (2016): 443-455. For the aeroplane as a dynamic form of technological sublime, see Nye, American Technological Sublime, 201-203.

${ }^{31}$ Malin, Feeling Mediated, 38. On a British rhetoric of the technological sublime, see Michael John Law, " "The flashy strings of neon lights unravelled"-motoring leisure and the potential for technological sublimity on the Great West Road', London Journal 39, no. 3 (2014): 281-294.

${ }^{32}$ David T. Courtwright, Sky as Frontier: Adventure, Aviation, and Empire (College Station: Texas A\&M University Press, 2005), 127-128; Michael John Law, The Experience of Suburban Modernity: How Private Transport Changed Interwar London (Manchester: Manchester University Press, 2014), 59-66; John Buckley and Paul Beaver, The Royal Air Force: The First One Hundred Years (Oxford: Oxford University Press, 2018), 3.

${ }^{33}$ Millward, Women in British Imperial Airspace, 29.

${ }^{34}$ Holman, 'The Militarisation of Aerial Theatre', 3-6. For earlier uses of the term 'aerial theatre', see Erkki Huhtamo, "The sky is (not) the limit: envisioning the ultimate public media display', Journal of Visual Culture 8, no. 3 (May 11, 2010): 329 348 , at 340 .

${ }^{35}$ Guy Debord, The Society of the Spectacle, translated by Ken Knabb (Berkeley: Bureau of Public Secrets, 2014); Thomas Richards, The Commodity Culture of Victorian England (Stanford: Stanford University Press, 1991), 54-58. 
especially, cinema followed. ${ }^{36}$ Organised sports, too, began to draw large crowds from the late nineteenth century. ${ }^{37}$ But spectacle is not confined to these modes. Its military roots, in particular, are deep, both on the battlefield and off it. ${ }^{38}$ Scott Hughes Myerly has identified a martial culture of display created by the British Army in the nineteenth century, focused particularly on grand reviews and, especially, equestrian drama. These spectacles performed and embodied values of 'Discipline and order, hierarchy, conformity, efficiency and esprit de corps', presenting the Army as a reassuring 'bulwark of both British rights and independence, and of the majesty, dignity and glory of the British monarchy and state'.$^{39}$ By the late Victorian period, as Jan Rüger has shown, the Royal Navy developed a parallel 'naval theatre' of fleet reviews and ship launches, in many cases consciously adapting military theatre for a maritime context. This in turn became part of a competitive Anglo-German culture of naval spectacles, used to promote images of national power. ${ }^{40}$ Military theatre and naval theatre were highly spectacular, hugely popular and extremely successful as propaganda, with an impact on the popular understanding of the role of the Army and the Navy in British society and on the world stage which, thanks to its amplification in the press and in memorabilia, far outstripped even the direct influence on the huge numbers of people who witnessed the parades and launches themselves.

Similarly, aerial theatre is a new way to understand the construction of airmindedness. Aerial theatre was, to a large degree, how airmindedness spread, by drawing attention to itself and inviting spectators to wonder at what was being performed for them. It was a mass form of popular culture which through its form and content made claims about the function and future of technology, and hence about the future of the nation itself. One of its

\footnotetext{
${ }^{36}$ Michael R. Booth, Victorian Spectacular Theatre 1850-1910 (Boston: Routledge \& Kegan Paul, 1981); Kathrin Maurer, 'The paradox of total immersion: watching war in nineteenth-century panoramas' in Anders Engberg-Pedersen and Kathrin Maurer (eds), Visualizing War: Emotions, Technologies, Communities (New York and Abingdon: Routledge, 2017); Tom Gunning, 'The cinema of attraction[s]: early film, its spectator and the avant-garde', in Wanda Strauven (ed.), The Cinema of Attractions Reloaded (Amsterdam: Amsterdam University Press, 2006), 381-388.

${ }^{37}$ Mike Huggins, The Victorians and Sport (London: Hambledon and London, 2004), $10-12$.

${ }^{38}$ Anastasia Bakogianni, 'War as spectacle, a multi-sensory event worth watching?' in Anastasia Bakogianni and Valerie M. Hope (eds), War as Spectacle: Ancient and Modern Perspectives on the Display of Armed Conflict (London: Bloomsbury Academic, 2015), 1-21.

${ }^{39}$ Scott Hughes Myerly, "“The eye must entrap the mind": Army spectacle and paradigm in nineteenth-century Britain', Journal of Social History 26, no. 1 (1992): 105131, at 114, 115. See also Dion Georgiou, 'Restaging Mafeking in Muswell Hill: performing patriotism and charitability in London's Boer War carnivals', Historical Research 91, no. 254 (2018): 744-771.

${ }^{40}$ Jan Rüger, The Great Naval Game: Britain and Germany in the Age of Empire (Cambridge: Cambridge University Press, 2007).
} 
most common forms was the air display, consisting of a variety of different aerial performances. These originated before 1914 as civilian and commercial enterprises. By the 1930s such 'barnstorming' displays had become larger and more organised, and often included some kind of simulated combat, especially when organised by air forces, as at Hendon. ${ }^{41}$ Another important form of aerial theatre was the air race, especially in the United States where short-course events were extremely popular, but also in Britain where the cross-country King's Cup was popular..$^{42}$ International races, such as the Schneider Trophy for seaplanes and the 1934 London-Melbourne Air Race, were also attended by large crowds and received much media attention. Record-breaking air expeditions by media-friendly aviators like Sir Alan Cobham and Amy Johnson also covered long distances and attracted huge interest in the interwar period. ${ }^{43}$ Air reviews, or flypasts, were commonly associated with dictatorships like Nazi Germany or the Soviet Union, but were also increasingly in vogue in Britain: George V reviewed 350 aircraft flying in formation on the occasion of his Silver Jubilee in $1935 .{ }^{44}$ The value of aerial theatre for projecting an image of strength and modernity to domestic and foreign audiences was enormous, as demonstrated by the mass transoceanic flights pioneered by the Italian Fascist Italo Balbo, or the agitflights of the giant Soviet Tupolev ANT-20. ${ }^{45}$ Yet, by virtue of the aeroplane's ability to transcend distance, aerial theatre could provide equally powerful internationalist propaganda too: huge crowds of Parisians greeted the American flyer Charles Lindbergh after his non-stop crossing of the Atlantic in 1927.46

Aviation, as a new and rapidly developing technology, had little tradition to rely upon. While aerial theatre was not inherently militaristic - and in fact began as purely civilian entertainment in the ballooning era of the late eighteenth century, remaining so almost entirely up until the First World War-many forms of aerial theatre were therefore adapted from older military and naval theatre: flypasts imitated fleet reviews, aerobatics resembled cavalry evolutions. Hendon itself was explicitly intended as a counterpart to `Naval and Military Assaults at Arms, regattas, regimental

${ }^{41}$ Dominick A. Pisano, 'The greatest show not on Earth: the confrontation between utility and entertainment in aviation', In Dominick A. Pisano (ed.), The Airplane in American Culture (Ann Arbor: University of Michigan Press, 2003), 39-74, at 51-59; Holman, 'The militarisation of aerial theatre'.

${ }^{42}$ Pisano, 'The greatest show not on Earth', 64-66; Jack Williams, "The upper class and aeroplane sport between the Wars', Sport in History 28, no. 3 (2008): 450-471.

${ }^{43}$ Wohl, The Spectacle of Flight, 279-294.

${ }^{44}$ Lincolnshire Echo (Lincoln), 6 July 1935, 1; A. Bowdoin Van Riper, Imagining Flight: Aviation and Popular Culture (College Station: Texas A\&M University Press, 2003), 44; Palmer, Dictatorship of the Air, 174-175.

${ }^{45}$ Wohl, The Spectacle of Flight, 69-70, 72-78, 88-100; Palmer, Dictatorship of the Air, 153.

${ }^{46}$ Wohl, The Spectacle of Flight, 9-3. 
sports and the like' ${ }^{47}$ But while the stern majesty of a line of battleships or the ranks of a marching regiment were undeniably visually impressive, they could not surpass the sheer dynamism of aircraft in motion. Combined with its previously mythical status, the highly technological spectacle of flight made it an almost ideal form of technological sublime. The meaning of these spectacles changed over time: air displays in the early twenty-first century, when aviation is a mature technology with a lengthening history, cannot have the same impact as those of the early twentieth century, when aviation was still all potential and its future only to be guessed at. ${ }^{48}$ Precisely because the aeroplane was so new, aerial theatre then was forward-looking, celebrating present and potential technological progress much more than past achievements. Indeed, spectacle was largely inseparable from progress itself: the first public flights of the Wright aeroplane in Europe in 1908 announced the aerial age, rather than its more secretive trials at Kitty Hawk five years earlier. In the following decades, at airfields all over the world, the public witnessed and so verified the advance of aviation with their own eyes. ${ }^{49}$

Despite the rapid advance of air transportation in the 1930s, not until well after the Second World War did civil aviation begin to play a practical role in the life of the wider public; before then, for most people the aeroplane was either a threat or an entertainment. For this reason, visions of war from the air could not be divorced from hopes that aviation would bring peace and prosperity and, despite its civilian origins, the aeroplane was, and was seen as, a predominantly military technology. ${ }^{50}$ Aerial theatre reflected and reinforced this confusion, or rather duality. Civilian forms of aerial theatre were initially dominant, but were always at risk of becoming partly militarised by the presence of air force aircraft or by the adoption of military forms of aviation spectacle. The First World War itself gave a huge boost to aerial theatre as well as to aeronautical technology; many veteran pilots went on to perform in aerial theatre afterwards, while from the late 1920s Hollywood aviation epics popularised the telling of exciting and melodramatic stories of wartime exploits. ${ }^{51}$ With the failure of disarmament and the prospect of another world war, air forces expanded from the mid1930s. Aerial theatre became more martial too; compared with the

${ }^{47}$ The National Archives [TNA], AIR 2/4427, letter, Chief of Air Staff [Air Marshal Sir Hugh Trenchard], 14 February 1921. See, generally, Eric Hobsbawm and Terence Ranger (eds) The Invention of Tradition (Cambridge: Cambridge University Press, 2012).

${ }^{48}$ Rech, 'A critical geopolitics of observant practice'; Philip Sabin, 'Airpower in British popular culture', RUSI Journal (8 August 2018): 2-7.

${ }^{49}$ Matthew F. Rech, 'A Critical Geopolitics of RAF Recruitment', PhD thesis, Newcastle University (2012), 115-117.

${ }^{50}$ David Edgerton, Warfare State: Britain, 1920-1970 (Cambridge: Cambridge University Press, 2006), 315-318; Kaplan, Aerial Aftermaths, 69-71, 75-76.

${ }^{51}$ Michael Paris, From the Wright Brothers to Top Gun: Aviation, Nationalism and Popular Cinema (Manchester: Manchester University Press, 1995). 
conscription and naval leagues before 1914, a more relevant and more entertaining form of militarism for an age of mass media and total war. ${ }^{52}$ The technological sublime of aerial theatre thus reflected the complex meaning of aviation, its promise and its peril, a prosperous peace or another total war. While the crowds came for the spectacle, they inevitably left with dramatic and often exaggerated ideas about what aviation was and what it could do, for the nation or to it, in peace, and in war.

\section{The Orientalisation of Hendon}

Most writing on Hendon follows in the footsteps of the pioneering work of Omissi, in which he argues that the Display helped promote RAF ideology and identity, and even its existence: created out of the aerial arms of the British Army and the Royal Navy in 1918, in wartime, for much of the 1920s it was at risk of dismemberment and even reabsorption by the older services. ${ }^{53}$ More narrowly, however, he is concerned with its portrayal of air control operations. Omissi's focus on Hendon's imperial themes is perfectly legitimate, particularly given his own foundational research on British air control policies, in which forts and villages were threatened with bombing, and sometimes actually bombed, in order to produce compliance to British demands-not incidentally, at significant savings in British manpower and finances, if at sometimes terrible cost to civilians. Air control was both a key role for the RAF in the interwar period and an important instrument of state violence against colonised people, particularly in the Middle East and India. ${ }^{54}$ But Omissi's historiographical successors have overlooked the fact that he largely confines himself to analysing only the four imperial set-pieces, those performed in 1922, 1923, 1927, and 1930, instead taking his analysis as representative of the eighteen-year history of the Display as a whole. His qualification that 'After 1932' - in fact, 1930-'the imperial set piece made way for dramas of European relevance' has apparently been little noticed. ${ }^{55}$ The opposite is true of his quotation of colourful, racialised terms such as 'Wot Knotts' and 'Irqestine' (sic), which were used only by one trade newspaper, and nowhere else. ${ }^{56}$ The reliance of later historians on Omissi's account has thus had the effect of making Hendon look much more imperial than it really was.

\footnotetext{
${ }^{52}$ Holman, 'The militarisation of aerial theatre'; Paul Virilio, War and Cinema: The Logistics of Perception (London: Verso, 1989), 97-98.

${ }^{53}$ Omissi, 'The Hendon Air Pageant', 199-200.

${ }^{54}$ David E. Omissi, Air Power and Colonial Control: The Royal Air Force 1919-1939

(Manchester: Manchester University Press, 1990). See also Chaz Bowyer, RAF

Operations 1918-1938 (London: William Kimber, 1988); Satia, 'The defense of inhumanity'.

${ }^{55}$ Omissi, 'The Hendon Air Pageant', 215.

${ }^{56}$ Ibid., 212, 214; cf. Flight, 29 June 1922, 373; Flight, 7 July 1927, 460.
} 
Year

1920

1921

1922

1923

1924

1925

1926

1927

1928

1929

1930

1931

1932

1933

1934

1935

1936

1937

\section{Target}

$\mathrm{n} / \mathrm{a}(1)$

Village

Fortress

Bridge

Commerce

raider

Commerce

raider

Aerodrome

Town

Oil refinery

Port

Plantation

Siege gun

Aerodrome

Submarine base (2)

Magazine

$\mathrm{n} / \mathrm{a}(1)$

Power station

Port

\section{Imperial \\ warfare?}

Industrial

warfare?
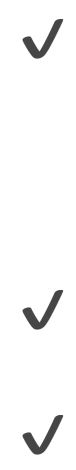

$\checkmark$
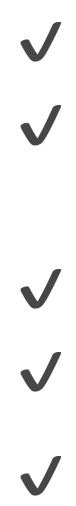

$\checkmark$

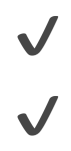

Table 1: Summary of Hendon set-pieces, 1920-1937. (1) In 1920 and 1935 there was no set-piece. (2) In 1933 the planned set-piece was not performed due to poor weather.

All of the set-pieces performed at Hendon are listed in Table 1. The 'imperial' ones were set in identifiably colonial contexts, involving a nonindustrialised enemy; the 'industrial' ones simulated attacks on military targets such as enemy bases and warships, or civilian ones such as cities, ports, or power stations. The imperial scenarios cast unspecified colonial 
enemies as the aggressors, with the RAF acting to defend European civilians and restore British control. In 1922, for example, the set-piece featured a RAF aeroplane with engine trouble being forced to land near a desert fortress occupied by a local tribe. Under attack, the stranded aircrew are assisted by an armoured car and mechanics brought in by air, and finally bombers send the fortress up in flames. As Omissi argues, this scenario, clearly inspired by the aerial campaign against the so-called 'Mad Mullah', Mohammed Abdullah Hassan, in British Somaliland in 1920, was 'political propaganda intended to justify the independence of the RAF by showing that it had an independent peacetime role - that of policing the empire on the cheap ${ }^{\prime}{ }^{57} \mathrm{~A}$ similar scenario was performed in 1923, by which time much more extensive air control policies were being implemented in Iraq, a British-controlled League of Nations mandate, unprecedentedly placed under RAF command. Air control operations in the Middle East and on the North-West Frontier substituted aerial surveillance and bombing for the usual large-scale punitive expeditions using ground forces. This appeared to be a cost-effective way of policing an empire overstretched after a costly war and the addition of new territories to govern. For the RAF, doing what the Army could do more quickly and cheaply helped to stave off threats to its independence, and gave its airmen valuable peacetime experience in navigation and bombing in challenging, warlike conditions.

The later representations of imperial themes at Hendon moved away from air control proper to more generic applications of airpower. In 1927 the setting was a 'native town', whose inhabitants attacked the 'small community of European traders', forcing white 'women and children' to flee'. A squadron of Fairey Fox bombers then 'attacks the town and pursuing natives with bombs and machine-gun fire', setting the village ablaze and allowing the Europeans to be flown to safety. ${ }^{58}$ Piracy was the theme in 1930 :

the crew of a vessel carrying munitions and aircraft, had seized the ship and taken refuge in a sparsely populated part of British Colonial territory. Having installed themselves in a planter's house (and murdered the planter and his staff!) they proceeded to erect the stolen aircraft with the intention of conveying (and ultimately disposing of) the booty to various destinations. ${ }^{59}$

Some of the other set-pieces had potentially colonial settings, in particular the various 'Port Hendon' scenarios which could just as easily stand for Port Said or Singapore as Liverpool or London. But in these cases the opponents were clearly industrialised, and so represented other nations or empires. A number of smaller-scale scenarios also presented some form of fictional battle

${ }^{57}$ Omissi, 'The Hendon Air Pageant', 203.

${ }^{58}$ Official programme, quoted in Aeroplane, 6 July 1927, $26,27$.

${ }^{59}$ Flight, 4 July 1930, 764. 
narrative to the audience, such as bombing displays or aerial combat. ${ }^{60} \mathrm{~A}$ handful of these revisited the imperial set-pieces of the 1920s. A demonstration of army co-operation in the 1932 Display centred on the defence of water wells against 'a desert raiding party', with support from 'friendly natives' ${ }^{61}$ In 1936,'A band of marauders has crossed the frontier, and having carried out a successful raid is returning home with the loot'; a squadron of fighters 'intercepts the evil-doers and carries out a low flying attack upon them' ${ }^{62}$ A similar scenario in 1937 substituted 'a band of pirates' ${ }^{63}$ Nevertheless, these minor elements were uncommon in the Display's history as a whole.

It is plain from Table 1 that the typical Hendon set-piece involved a technologically sophisticated enemy in an industrialised landscape, rather than desert fortresses or Middle Eastern villages. Only four set-pieces were set in identifiably imperial contexts, the last of which was no later than 1930. That is, only a quarter of the sixteen Hendon set-pieces were imperial; even in the period up to and including 1930, the proportion was only one in three. Put another way, only two of the thirteen set-pieces after 1923 were had colonial settings. Even after accounting for both set-pieces and minor elements, imperial themes remained only a minor component of the Display. It follows that Hendon was not primarily a vehicle for imperial propaganda.

This is surprising, because air control was the RAF's major preoccupation for most of the interwar period. Doctrinally, as Neville Parton demonstrates, for most of the interwar period 'the area in which greatest effort had been expended was that of counter-insurgency, or air policing to be correct'; even by 1935 `RAF doctrine was still not focussed on the emerging types of threats to stability in Europe' ${ }^{64}$ Since air control was so important to the RAF, why was it not more prominent at Hendon? Omissi suggests that the RAF 'gradually modified the imperial set pieces of the 1920s to accommodate the objections of their critics, before eventually replacing them by forms of spectacle more suited to the climate of fear created by the failure of the Geneva disarmament conference and the rise of the Luftwaffe' ${ }^{65}$ Indeed, Communist and Labour MPs criticised the mock bombing of Arab villages in 1922 and 1927; as late as 1936, the Air Ministry had to assure the Peace Committee of the Society of Friends that the 'marauders' in that year's low-level bombing demonstration 'belonged to a race of white savages of unknown origin who, it was thought, might have come from the moon' ${ }^{66}$ Clearly, pacifist and left opinion was

${ }^{60}$ Omissi, 'The Hendon Air Pageant', 213-214.

${ }^{61}$ Official programme; quoted in Flight, 1 July 1932, 588.

${ }^{62}$ Programme of the Royal Air Force Air Display 1936 (n.d. [1936]), 59.

${ }^{63}$ Flight, 1 July 1937, 9.

${ }^{64}$ Parton, 'The Evolution and Impact of Royal Air Force Doctrine', 156, 157.

${ }^{65}$ Omissi, 'The Hendon Air Pageant', 216.

${ }^{66}$ Cecil L'Estrange Malone, oral question to Frederick Guest, 6 July 1922,

Parliamentary Debates, vol. 156, col. 557, https://api.parliament.uk/historic-

hansard/commons/1922/jul/06/hendon-pageant, accessed 19 February 2019; J.M. 
sensitive to this issue. On the other hand, every scenario had to be vetted in this way, imperial or not: as C.G. Grey, editor of The Aeroplane, observed, they must avoid 'anything that is likely to offend any foreign nation, from the United States to the Republic of Andorra, and people are so touchy these days' ${ }^{67}$ Moreover, by 1935, when the threat of German aerial rearmament became clear, it had been five years since any imperial themes had last been represented at Hendon. Embarrassment was not the reason for the decline. Rather, a different argument was being made.

\section{Staging independent airpower}

Twelve of the sixteen Hendon set-pieces, or fully three-quarters, were set in identifiably industrial contexts. These included the first, in 1921 and the last, in 1937; and the majority of those before, and all of those after, 1930. Overall, industrialised wars were simulated in Hendon's set-pieces far more often than imperial ones, by a ratio of about three to one. This shifts the weight of Hendon's spectacles from the periphery back to the centre. They were not primarily about convincing the British people of the RAF's ability to quell revolts on the edges of empire, but rather of its ability to fight another major war in Europe, most likely against the Soviet Union, Italy or Germany. Hendon was less a demonstration of imperial air power than it was of independent, or strategic, airpower, which could win wars unaided.

Until the last year of the First World War, British airpower had always been under the control of the British Army and, from 1914, the Royal Navy. The popular outcry over the Gotha air raids on London in 1917 as well as the increasingly complex demands of aircraft production led to the creation of an independent service, the RAF, combining the aircraft and personnel of the Royal Flying Corps and the Royal Naval Air Service. ${ }^{68}$ With the end of the war so soon afterwards, the Army and the Navy exerted pressure to try to recover their own air arms, if not to disband entirely the RAF, now a rival for limited defence spending. The argument of airpower advocates that aircraft could substitute for troops and warships was potentially powerful, and the evident success of air control in Iraq did help to justify the RAF's existence. However, as Parton argues, this was not in itself sufficient, as these functions could have been carried out by an aviation corps subordinate to the Army. ${ }^{69}$ The vulnerability of battleships to bombers could have been countered in a similar

Kenworthy, oral question to Sir Philip Sassoon, 4 July 1927, Parliamentary Debates, vol. 208, cols. 864-865, https: / / api.parliament.uk/historic-

hansard/commons/1927/jul/04/royal-air-force-display-hendon, accessed 19

February 2019; TNA AIR 2/4440, letter, J.M. Spaight [for Air Council], 27 July 1936.

See Parton, 'The Evolution and Impact of Royal Air Force Doctrine', 107-109.

${ }^{67}$ Aeroplane, 30 June 1937, 786.

${ }^{68}$ Overy, The Birth of the RAF.

${ }^{69}$ Parton, 'The Evolution and Impact of Royal Air Force Doctrine', 101, 156-157, 231. 
way by the Navy, which did eventually recover control of ship-borne naval aviation, in $1939 .{ }^{70}$ Parton describes the confusion within the RAF as to how to resolve this dilemma:

There was therefore also a clear need to argue for the ability of air power to deliver something that was unique to an independent Air Force, even if the RAF's view on what that 'something' was had yet to be completely agreed on-was it the much-feted knockout blow or instead the need to wrest control of the air and hence enable the other Services to operate without hindranceand with the ability to exploit that control in their favour? ${ }^{71}$

The RAF Display was the popular counterpart of this internal debate. Initially concerned to avoid needlessly offending the senior services, RAF doctrine initially focused on the immediate tasks of air control. This shifted to a greater interest in strategic bombing from 1922, and a much more rounded conception of independent airpower by the mid-1930s. ${ }^{72}$ Cumulatively, the image presented at the Display was that airpower was able to substitute for the Army and the Navy, as well as to operate independently, in any conceivable war in which Britain could be involved. In other words, Hendon was one long argument for airpower supremacy.

Initially, the First World War was refought at Hendon, a counterpart to the 'hyper-realistic' attempts by local communities to commemorate the war through historical pageants. ${ }^{73}$ In 1920, the very first Display had no set-piece, but it did include a demonstration of the RAF's battlefield support role on the Western Front in the form of an attack by Bristol Fighters on a trench:

As they swooped away the whole trench leaped upwards in a sheet of flame, surmounted by a rolling cloud of black smoke, which brought home to thousands one of the grimmer realities of war, and the deadliness of the modern aeroplane in attacking infantry. ${ }^{74}$

In 1921, the first set-piece proper was given clearly German characteristics, a village said to be a military headquarters of 'Gen. Blitzenscooter', defended by an apparently genuine German Albatros fighter. ${ }^{75}$ Even the imperial set-

\footnotetext{
${ }^{70}$ Barry D. Powers, Strategy Without Slide-Rule: British Air Strategy 1914-1939 (London: Croom Helm, 1976), 138-142, 174-177.

${ }^{71}$ Parton, 'The Evolution and Impact of Royal Air Force Doctrine', 102.

${ }^{72}$ John Robert Ferris, Men, Money and Diplomacy: The Evolution of British Strategic Foreign Policy, 1919-26 (Ithaca: Cornell University Press, 1989), 69; Parton, 'The Evolution and Impact of Royal Air Force Doctrine', 215-224; Malcolm Smith, British Air Strategy Between the Wars (Oxford: Clarendon Press, 1984), 320.

${ }^{73}$ Angela Bartie, Linda Fleming, Mark Freeman, Tom Hulme, Paul Readman, and Charlotte Tupman, " "And those who live, how shall I tell their fame?" Historical pageants, collective remembrance and the First World War, 1919-39', Historical Research 90, no. 249 (2017): 636-661, at 646.

${ }^{74}$ Sphere, 10 July 1920, 10.

${ }^{75}$ Flight, 7 July 1921, 456.
} 
pieces looked back as much as forward: in 1923, Flight declared that the aerial support of ground troops against desert tribes depicted in that year's set-piece was 'based on actual happenings during the War' ${ }^{76}$ Here, airpower was portrayed as an aid to ground forces, not a substitute.

Making a virtue of the RAF's short history compared with the Army and the Navy, recreating the past was soon abandoned in favour of scenarios depicting generic future conflicts, emphasising how airpower was revolutionising modern warfare. From the mid-1920s the purported ability of aircraft to dominate in naval warfare began to emerge as a major theme at Hendon. Even in the 1922 'desert stronghold' scenario had originally been intended to show aircraft sinking a battleship, until the Navy objected. ${ }^{77}$ The 1924 and 1925 scenarios both featured naval settings. The former, for example, portrayed a tramp steamer intercepted by a hostile merchant cruiser, both impressively simulated by huge stage props, with the literally Slavicsounding, and so presumably Soviet, Slevic preparing to board the British ship when RAF torpedo bombers arrive and sink it. ${ }^{78} \mathrm{~A}$ 'foreign defended port overseas' was the target in 1929. With a troopship at the quay and smaller vessels in the harbour, this was an unusually elaborate set, matched by an unusually elaborate geopolitical background, involving a failed League of Nations mediation over 'the disputed boundary of a British overseas possession', over which Britain launches a pre-emptive strike by a 'force of heavy bombers, together with an aircraft carrier' against a foreign port. That the enemy here was also meant to suggest the Soviet Union is suggested by Flight's description of the defending fighters as 'Siskinskys', that is, fauxRussianised Armstrong-Whitworth Siskins. ${ }^{79}$ Army co-operation also featured frequently, whether in the imperial set-pieces or in the minor events, such one in 1924 featuring a 'low-flying attack on a disabled tank [...] with machine guns and bombs' ${ }^{80}$ The 1929 programme included three demonstrations of low-level attacks on ground targets, such as lorries and encampments, and two of aerial interception of bombers, in addition to the set-piece itself..$^{81}$ Even the whimsical air skittles event involved dropping bombs on giant bowling pins, thus demonstrating aiming accuracy.

Finally, some Hendon scenarios emphasised the RAF's ability to carry out long-distance, strategic strikes, beyond the domains of the Army or the Navy. In the 1931 set-piece, the target was a 'long-range gun' nestled among 'deserted farm buildings'; in 1932, it was an 'enemy aerodrome and fort' ${ }^{82}$ In 1936, the penultimate set-piece featured an unambiguously strategic target.

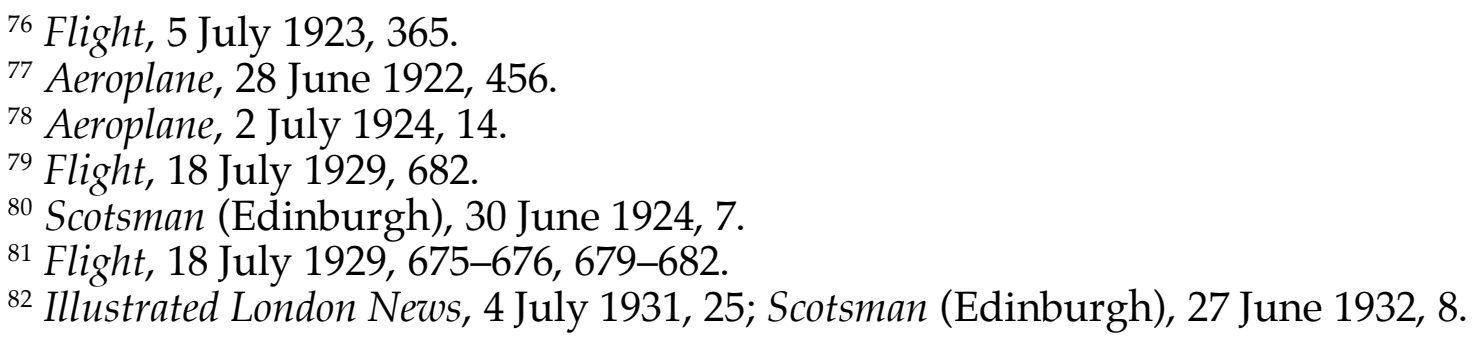


According to the official programme,

NORTHLAND has been trying for some time to force a decision by bombing objectives, the destruction of which will seriously hamper SOUTHLAND'S production of war material. The power station in the north corner of the aerodrome is such an objective, since it is supplying electrical power to a group of munition factories. It is known that the NORTHLAND command is contemplating an attack on this power station with a group of bombers. ${ }^{83}$

The minor items which made up the bulk of each Display also frequently featured independent airpower. In 1927, for example, the set-piece destruction of the 'Eastern' village and rescue of European civilians was immediately preceded by another mock battle, a representation of the air defence of London:

Hostile bombing squadrons will endeavour to attack London from the north, and, following the receipt of wireless intelligence, fighter squadrons from the London Defence station at Hendon will ascend to intercept the raiders. A spectacular battle will ensue, in which the airmanship, both of attackers and defenders, is full of realism. Several machines will be brought down. ${ }^{84}$

A similar event was performed the following year. ${ }^{85}$ The altitude race introduced in 1927 involved a rapid climb for 15 minutes, simulating the scramble of the fighter squadrons 'ringing London with their protective power' to intercept incoming enemy bombers. ${ }^{86}$ In 1935, the set-piece was replaced by a fly-past of nearly 80 aircraft. This substitution of mass and noise for speed and skill was, perhaps, intended as both a reassuring image and a threatening message after the recent revelation of Germany's illegal aerial rearmament and the start of the RAF's own, far from complete, expansion, itself intended to deter an attack through numbers more than capability. ${ }^{87}$ Its message was reinforced by two earlier events that day simulating the air defence of London, in which first fighters and then anti-aircraft guns took their toll of the raiders. ${ }^{88}$

The mock battles performed at Hendon largely oversold the extent to which the RAF was capable of undertaking an independent role in a major war. While the imperial set-pieces were partly the product of actual experience, before 1939 the effects of air raids on submarine bases or oil

${ }^{83}$ Programme of the Royal Air Force Air Display 1936 (n.d. [1936]), 73.

${ }^{84}$ Belfast News-Letter, 31 May 1927, 6.

${ }^{85}$ Flight, 28 June 1928, 483.

${ }^{86}$ The Times, 2 July 1927, 13.

${ }^{87}$ Flight, 4 July 1935, 11.

${ }^{88}$ Programme of the Royal Air Force Air Display 1935 (n.d. [1935]), 73. 
refineries could only be imagined. Just as there was no consensus before the late 1930s as to how to put independent airpower doctrine into effect, there was little capability to do so, in terms of training or equipment. Hence the use of Fairey Gordon and Westland Wallace light bombers to destroy a munitions factory in the 1934 Display, an operation for which they would have been illsuited in terms of range and bomb-load; the RAF, as yet, had few aircraft more appropriate to the task. ${ }^{89}$ No British naval vessels were portrayed in the naval scenarios. While British ground forces did sometimes feature, they were always shown as being incapable of destroying enemy forces unaided; only the timely intervention of RAF aircraft saved the situation. At Hendon, the RAF's true enemy was not Iraqi rebels or the German air force, but the Army and the Navy.

\section{From the technological sublime to the knock-out blow}

The near-total absence of civilians in the RAF Display's aerial theatre gave the misleading impression that modern war could be confined to combatants. But the ambiguous nature of the technological sublime at Hendon enabled other readings. This mattered little in the first decade of Hendon's existence, when hopes were high that the League of Nations would be able to keep the world at peace while disarmament removed the threat of war. By the mid1930s, however, the danger signs multiplied, and it was widely assumed that the next war would begin in the air, as the opposing air forces bombed each other's cities in the attempt to achieve a knock-out blow. It became ever harder to see the bomber as anything other than a grave threat to civilisation itself. $^{90}$ The spectacular nature of Hendon, which the RAF relied upon to promote its own version of its usefulness in war, began to undermine its intended meaning.

The huge crowds did not come to Hendon for the militarism, not directly. Instead, they came for the spectacle. That Hendon was widely perceived to be spectacular is clear, as it was almost universally described in superlatives which evoked its power to impress:

The greatest thrill of the year is the great aerial pageant held next Saturday at Hendon, when the most daring manoeuvres, the most spectacular stunts, the most hair-raising escapes are watched by an enthralled crowd..$^{91}$

Contemporary press accounts continually stressed the emotional engagement of audiences with the flying displays, to confirm the spectacular nature of what they were seeing and to convey the feeling of being there: 'All around

${ }^{89}$ Neville Jones, The Beginnings of Strategic Air Power: A History of the British Bomber Force 1923-1939 (London: Frank Cass, 1987), 50-70.

${ }^{90}$ Holman, The Next War in the Air, 50.

${ }^{91}$ Sphere, 20 June 1931, 519. 
me were chattering and excited spectators, all with faces upturned to the skies', as one observer reported. ${ }^{92}$ The unfolding of the meticulously planned aerobatic displays was admired much as a choreographed ballet might be; the misadventures of purposefully inept 'trainee' pilots drew comparisons with comedic circus acts. One writer struggled to remember that 'They are men up there', marvelling at the 'machines swooping around in antics so incredible that it seems that they cannot be directed by any human agency'. ${ }^{93}$ Flight waxed lyrical about the beauty of the 1935 Display, describing it as 'a gorgeous spectacle, dazzling all eyes with every variety of flashing, glimmering, floating argent against a background of blazing azure'.$^{94}$ The press stressed the theatricality of the Display much more than its potential for educating the viewer in aviation. Previews ran under headlines like 'A great pageant of flight'; The Bystander informed the reader of 'the cast for last Saturday's sky show'. ${ }^{95}$

The warlike aspects of Hendon were not always the most spectacular. The Beardmore Inflexible in 1928 and the R101 airship in 1930-the latter 'one of the most popular items on the programme', according to Flight-excited interest because of their huge size, not for their potential use in war. ${ }^{96}$ Other elements attracted attention because of their novelty, highlighting technological progress, such the Cierva autogyro, a kind of helicopteraeroplane hybrid, or radio direction from the ground of machines in the air. Conversely, a number of the set-pieces seem to have made little impression on those watching; few press accounts had anything to say about the aerodrome set-piece in 1932, for example, and the 1935 flypast was described by Flight as 'unimpressive'. ${ }^{97}$

Although most of the spectacle on display at Hendon was not inherently violent-in 1936, for example, only six out of the nineteen elements presented any kind of combat narrative-the ostensibly more technical performances such as formation flying or aerobatics also embodied messages about the critical importance of speed and accuracy in modern warfare. ${ }^{98}$ In 1935 readers of the official programme were informed that one display of formation aerobatics-involving such elements as a 'Half-roll off a loop in "V" formation' and a 'upward full-roll in line abreast' — required, and hence demonstrated:

(a) Absolute air discipline.

\footnotetext{
${ }_{92}$ Evening Telegraph and Post (Dundee), 4 July 1927, 2.

${ }^{93}$ Sunday Times, 26 June 1932, 16 (emphasis in original).

${ }^{94}$ Flight, 4 July 1935, 5.

${ }^{95}$ Graphic, 9 July 1927, 42; Bystander, 1 July 1936, $24-25$.

${ }^{96}$ Flight, 5 July 1928, 528; Flight, 4 July 1930, 747.

${ }^{97}$ Flight, 4 July 1935, 11.

98 Programme [1936].
} 
(b) Complete and precise control by each pilot over his aircraft.

(c) An exact judgement of speed..$^{99}$

Discipline, control, judgement: these were the virtues of the British airmanand, by extension, of an airminded Britain. ${ }^{100}$ The skills on display were both useful and reassuringly common: as one spectator thought, 'it looked so easy, this forming into column, double line, wedge shape and anon breaking up to form two perfect circles in the air [...] a better line than many of the ground troops at the recent Aldershot review' ${ }^{101}$ The aircraft at Hendon promoted a reassuring image of British aviation progress and hence British modernity, with the latest prototypes often making their public debut including, in 1936, both the Supermarine Spitfire and the (as yet unnamed) Hawker Hurricane, which in 1940 both became key factors in the Battle of Britain. ${ }^{102}$ Races served to show off the performance of RAF aircraft. From 1931 the Displays began to feature a flypast of pioneer aircraft, some dating to before 1914, contrasting with and so underscoring the progress being made by aviation.

For some spectators, the aesthetic pleasure of watching Hendon was not despite its ultimately warlike nature, but because of it. Central to the Display's success as aerial theatre were the dynamism and excitement of speed and violence; the fearful wonder of the technological sublime was part of the attraction. Flight's correspondent wrote that 'the airy rat-tat-tat of machine guns' and 'the solid thud of bombs' were 'sounds that, in their true settings, strike fear into the hearts of men, but which here play only the part of a theatre orchestra, giving zest and gaiety to the spectacle'. ${ }^{103}$ The Evening Telegraph's correspondent described one mock aerial combat:

Here were thrills galore. 'Planes were sent hurtling to earth, blazing fiercely. 'Plane after 'plane of the attackers 'crashed' amidst the awed gasps of the spectators, while the victors performed all manner of joyous stunts amid the smoke clouds. ${ }^{104}$

Destruction was exciting, too. In 1931, the crowd was said to be 'thrilled' by the destruction of a village and siege gun, while in 1936 Flight was impressed by the violence on display: 'in a few seconds the unlucky power station's volts, amps and ohms are being split into atoms in a terrific welter of smoke, flame and noise'. ${ }^{105}$ According to the Scotsman, the 1937 Display 'was an amazing demonstration with machines of awe-inspiring power, which gave a

\footnotetext{
${ }^{99}$ Programme [1935], 55.

${ }^{100}$ Adey, “'Ten thousand lads"'. But see also Francis, The Flyer, 16-18.

${ }^{101}$ Grantham Journal, 5 July 1924, 5.

102 Flight, 2 July 1936, 11. See Garry Campion, The Good Fight: Battle of Britain

Propaganda and the Few (Basingstoke: Palgrave Macmillan, 2009), 47.

${ }^{103}$ Flight, 1 July 1937, 4.

${ }^{104}$ Evening Telegraph and Post (Dundee), 4 July 1927, 2.

105 Nottingham Journal, 29 June 1931, 7; Flight, 2 July 1936, 11.
} 
vivid idea of the terrors of modern war in the air'. ${ }^{106}$

Despite the widespread assumption that civilians would be the first victims of the next war, they were almost never portrayed in Hendon's mock battles. The only clear exception was in 1921, in the very first set-piece, in which German civilians-including 'gaily dressed fräuleins' —-were shown as victims:

the Bristol Fighters swooped down, firing bursts from their machineguns, scattering the remainder of the occupants of the village, and as they passed over the village 'released' their bombs [...] the Bristols made a second attack on the by then merrily burning village and pretty-well wiped it out. ${ }^{107}$

While indigenous villages were also bombed in the following imperial setpieces, in 1922 and 1923, women and children were not seen, although their simulated homes were bombed and destroyed. Indigenous men, by contrast, were portrayed as violent or rebellious, and hence unproblematically valid targets. No civilians were shown in the later industrial, European set-pieces either. Thanks to carefully-controlled pyrotechnics target buildings could be destroyed without fail, while clearly non-military structures were spared.

Even with the explanations given in the souvenir programmes and over the aerodrome's loudspeakers, the RAF could not control how spectators understood what they were seeing. Given that in mock combat the RAF had to play both sides, it was easy for people watching to interpret the scenarios according to their pre-existing understanding of aerial warfare, which increasingly meant the theory of a knock-out blow from the air. These beliefs gathered strength from the late 1920s, thanks in large to scaremongering by pacifists and militarists. They only became more plausible after the failure of the Geneva Disarmament Conference in 1932 and then the 1935 panic over the revelation that Germany had not only illegally formed an air force but would soon overtake Britain in airpower. A devastating war in the air seemed increasingly likely, and the British government accelerated RAF rearmament, and belatedly began a programme of Air Raid Precautions (ARP). ${ }^{108}$ At Hendon, despite the deliberately nondescript names of 'Southland' and 'Northland' in the 1936 set-piece, the crowd readily identified the aggressors as 'Germans':

later, when the power station was blown up, despite the thoughtful explanation of the commentator that the dice was heavily loaded in favour of the bombers for the sake of the spectacle, the feelings of the crowd were

106 Scotsman (Edinburgh), 28 June 1937, 13.

${ }^{107}$ Flight, 7 July 1921, 456.

108 Phillip S. Meilinger, 'Clipping the bomber's wings: the Geneva Disarmament Conference and the Royal Air Force, 1932-1934', War in History 6, no. 3 (1999): 306330; Holman, 'The air panic of 1935'. 
epitomised by a spectator who remarked gloomily as he left the field: 'It might have been Battersea power station.' ${ }^{109}$

One observer thought that this set-piece evoked 'Something of the grimness of the air menace conjured up vividly in the screen version of H.G. Wells's "Things To Come"', with its depiction of the destruction from the air of a very London-like city. ${ }^{110}$ The London correspondent for the Nottingham Evening Post thought Hendon's value lay in 'reassuring nervous citizens at this time of the power and efficiency of our air force'. ${ }^{111}$ Some hoped it had a deterrent value: in 1937, Grey reported overhearing a spectator exclaim 'Well! That will show the foreigners that England is really building an Air Force'. ${ }^{112}$

Conversely, the Birmingham Gazette's correspondent thought it impossible to 'eliminate the sinister from the Pageant', remarking that 'The bombing displays shocked people, despite the jocular running commentary'. ${ }^{113}$ 'Fancy raids of that size coming over all day long', was another comment reported by Grey during the 1937 flypast. ${ }^{114}$ Even imperial set-pieces were becoming less amusing. In the 1936 'marauder' scenario, where the RAF had insisted that the targets were white, 'When the naughty savages yelled their war-cries the people thought of Harar', recently destroyed by Italian aircraft during the invasion of Abyssinia. ${ }^{115}$ By the mid-1930s, it was already becoming difficult for aerial theatre's spectators to ignore the potential implications of aviation for the future of civilisation. From 1938, after the widespread bombing of civilians in Spain and China, and the threat to London during the Sudeten crisis, it would be impossible. ${ }^{116}$

\section{Conclusion}

The last RAF Display was held on 26 June 1937, a victim, according to the Air Ministry, of the increasing difficulty of effectively displaying ever-faster aircraft within a confined space. ${ }^{117}$ But its successor was already in place. Held at RAF stations around the country each May between 1934 and 1939, Empire Air Day was intended to be a different model of aerial theatre to Hendon. Rather than a single set of events being held at a central location, on Empire

\footnotetext{
${ }^{109}$ Birmingham Gazette, 29 June 1936, 6.

${ }_{110}$ Northern Whig and Belfast Post, 29 June 1936, 6. See Christopher Frayling, Things to Come (London: BFI Publishing, 1995).

111 Nottingham Evening Post, 29 June 1936, 6.

112 Flight, 30 June 1937, 785.

113 Birmingham Gazette, 29 June 1936, 6.

${ }^{114}$ Flight, 30 June 1937, 785.

115 Birmingham Gazette, 29 June 1936, 6.

${ }^{116}$ Robert Stradling, Your Children Will Be Next: Bombing and Propaganda in the Spanish Civil War 1936-1939 (Cardiff: University of Wales Press, 2008); Holman, The Next

War in the Air, 203-219.

117 Flight, 27 January 1938, 93; Oliver, Hendon Aerodrome, 110.
} 
Air Day each station put on its own programme and invited the local populace to see how the air force really worked. ${ }^{118}$ The sheer number of aerodromes opened to the public in this way was impressive: by 1939 Empire Air Day was being held at 62 RAF stations and 16 civil aerodromes across the nation, from Abbotsinch to Yeadon. ${ }^{119}$ While the attractions included demonstrations of relatively low-key activities like aircraft maintenance and aerial navigation, many stations also ended up putting on Hendon-style setpieces, each with their own particular scenario. For example, the 1938 programme at Thornaby, a RAF aerodrome in the North Riding of Yorkshire, represented an attack on 'the desert village of Muhami', the fictional home of 'the Mullah of Dopi [who] has been carrying out fanatical anti-British propaganda', which 'is quickly reduced to ashes' ${ }^{120}$ Meanwhile, at the RAF station at Upper Heyford in Oxfordshire the most spectacular Empire Air Day event was an attempt by enemy bombers to deliver a knock-out blow:

On the far side of the aerodrome the set piece-an oil refinery-had been built, and as they passed over the attacking aeroplanes bombed it with high explosive bombs, and set it alight. Some of the raiders were hit by the antiaircraft guns. Others turned back and flying at a low altitude attempted to complete the destruction of the refinery with incendiary and gas bombs.

After the sounding of the 'air raid warning signal', spectators were then given 'an excellent idea of the precautions that are mapped out to deal with such attacks'.121

After Hendon, then, the RAF continued to use aerial theatre to promote the same gospel of independent airpower: that, when compared with traditional forms of military and naval power, the air weapon was the best weapon for any wars Britain was likely to fight. Air control was just one aspect of the British use of airpower between the wars, and from the early 1930s its importance to the RAF was declining. Similarly, Hendon was more than a simple reflection of British racism. This is not to say that the Display was not also a manifestation of popular imperialism. Omissi is clearly correct to read Hendon in this way. In fact, when Hendon was emulated elsewhere, versions of the imperial set-pieces often figured prominently. In Fascist Italy the Regia Aeronautica put its own air displays in 1930 and 1932 with set-pieces

${ }^{118}$ Rowan Thompson, 'The Air League of the British Empire, Empire Air Day and the creation of "airmindedness" in the 1930s", Four Nations History Network, 19 June 2017, https: / / fournationshistory.wordpress.com/2017 / 06/19/ the-air-league-of-thebritish-empire-empire-air-day-and-the-creation-of-airmindedness-in-the-1930s/, accessed 14 February 2019.

${ }^{119}$ Flight, 18 May 1939, 519-520.

${ }^{120}$ Royal Air Force Official Programme Empire Air Day (n.d. [1938]);

https: / / www.flickr.com/photos/96127522@N04/11107324863/in/album$72157633816734579 /$, accessed 14 February 2019.

${ }^{121}$ Banbury Advertiser, 2 June 1938, 2. 
portraying the destruction of an 'Arab village'. ${ }^{122}$ In 1928, the South African Air Force carried out a mock bombing attack on an 'Arab village', and may have put on Hendon-style displays in the late 1930s. ${ }^{123}$ As with the RAF, these simulated air raids paralleled real ones carried out on indigenous subjects. ${ }^{124}$ RAF commands overseas also performed their own versions of Hendon: in Iraq in 1924, 'Complete with machine guns, firebombs, armored [sic] cars, an artificial village, and stage fugitives'; at Delhi in 1927, 'witnessed by a large crowd of Indians'; and annually at Heliopolis in Egypt throughout the 1920s and 1930s. ${ }^{125}$ Here, aerial theatre was itself, in effect, air control, not just a representation of it: as early as 1918, a RAF pilot carried out bombing displays in South Africa, with 'a great effect on the native mind'. ${ }^{126}$

In the imperial metropole, aerial theatre had a different function. SaintAmour argues that

By racially sorting bomber from bombed, the pageants asserted an absolute difference between the service's colonial operations and the white-on-white bombardments of the Great War. Under cover of these extrovert dramas, the RAF held to its unutterable brief: hone the techniques of total war in colonial air control. ${ }^{127}$

To the contrary, the RAF's vision of total war at Hendon did embrace the bombing of white people as well as black: the only time civilians were shown being bombed was in 1921, when they were indicated as Germans. What it focused on was industrialised warfare, which would strike at the technological and industrial infrastructure necessary to support both military operations and civilian life. This liberal militarism asserted itself even in the miniature Hendons overseas: the RAF's Heliopolis display in 1935 ended with a set-piece depicting an air raid on an oil refinery, rather than a 'native' village. ${ }^{128}$ The exaggeration of the imperial themes at Hendon parallels a strand of the wider historiography on aerial bombardment, which emphasises strategic bombing theory and practice in the colonial periphery, rather than the European centre. ${ }^{129}$ Certainly, racist discourses of martial peoples who

${ }^{122}$ Omissi, 'The Hendon Air Pageant', 211; Wohl, The Spectacle of Flight, 86, 88.

${ }^{123}$ Pirie, 'British air shows in South Africa", 53; Albert Grundlingh, 'The King's Afrikaners? Enlistment and ethnic identity in the Union of South Africa's Defence Force during the Second World War, 1939-45', Journal of African History 40, no. 3 (1999): 351-365, at 355-356.

${ }^{124}$ James J. Sadkovich, 'The development of the Italian Air Force prior to World War II', Military Affairs 51 (1987): 128-136; Tilman Dedering, 'Air power in South Africa, 1914-1939', Journal of Southern African Studies 41, no. 3 (2015): 451-465.

${ }^{125}$ Saint-Amour, 'On the partiality of total war', 445; Bowyer, RAF Operations, 182, 184; Flight, 7 February 1935, 146.

${ }^{126}$ Quoted in Dedering, 'Air power in South Africa', 454.

127 Saint-Amour, 'On the partiality of total war', 444.

${ }^{128}$ Flight, 7 February 1935, 146.

${ }^{129}$ Michael Paris, 'Air power and imperial defence, 1880-1919', Journal of 
somehow had 'no objection to being killed', as former Chief of the Air Staff Sir Hugh Trenchard claimed in 1930, served as a convenient justification for their use as target practice by a generation of RAF airmen. ${ }^{130}$ However, as with Hendon, to focus solely on this imperial perspective can obscure more than it reveals. As much as it was in actual practice used against imperial subjects in the 1920s and 1930s, in the end air control was a secondary mission for the RAF. Far from using it to hone the techniques of total war, Britain never unleashed its colonial bombers against densely populated urban centres and its limited operations in the Middle East and the North-West Frontier were little preparation for total war over Europe. ${ }^{131}$ For the British, the strategic bomber was ultimately aimed at the white, European working class-either directly, at enemy civilians, or indirectly, at the enemy economy. ${ }^{132}$

The meaning of Hendon, then, was that the next war was to be a war from the air, and that the RAF would win it. This was not only an argument for institutional survival but a promise that independent airpower, in the form of the bomber, would prevent another protracted trench war-if only at great risk to civilians, in the European metropoles as well as on the imperial periphery. ${ }^{133}$ It was the popular projection of the RAF's value to the warfare state in this interwar era, and the Display was its contribution to British militarism. The two senior services, by and large, did not try to interpret modern warfare for the public. The spectacularity of military and naval theatre was also very popular in the interwar period; 76,000 people attended the first day of the Aldershot Tattoo in 1934, for example; in 1936, a record 435,000 came to Portsmouth, Plymouth and Chatham across Navy Week. ${ }^{134}$ But they tended to recreate past glories rather than forecast future warfare. The Royal Navy held four fleet reviews in the interwar period, but ignored the peril of submarine warfare in favour of long lines of grey warships; rather bizarrely, in 1934 the British Army's Northern Command Tattoo at Gateshead reenacted the French destruction of Moscow in $1812 .{ }^{135}$ The RAF, by contrast,

Contemporary History 24, no. 2 (1989): 209-225; Lindqvist, A History of Bombing; Thomas Hippler, Governing from the Skies: A Global History of Aerial Bombing (London: Verso Books, 2017), 56-76. See also Christiane Wilke, 'How international law learned to love the bomb: civilians and the regulation of aerial warfare in the 1920s', Australian Feminist Law Journal 44, no. 1 (2018): 29-47.

${ }^{130}$ Quoted in Satia, 'The defense of inhumanity', 37. See also James S. Corum and Wray R. Johnson, Airpower in Small Wars: Fighting Insurgents and Terrorists

(Lawrence: University Press of Kansas, 2003), 62-63.

${ }^{131}$ Overy, The Bombing War, 49; Buckley and Beaver, The Royal Air Force, 31, 32, 42-44;

132 Beau Grosscup, Strategic Terror: the Politics and Ethics of Aerial Bombardment (London: Zed Books, 2006), 36-43; Holman, The Next War in the Air, 44-49.

${ }^{133}$ Amanda Alexander, 'The "Good War": preparations for a war against civilians', Law, Culture and the Humanities, no. 1 (2016): 227-252.

${ }^{134}$ Hampshire Telegraph (Portsmouth), 22 June 1934, 23; Gloucester Journal, 15 August 1936, 20.

${ }^{135}$ Rüger, The Great Naval Game, 259-61, 267-270; Northern Command Tattoo 1934 (Newcastle upon Tyne: Andrew Reid, 1934); in Tyne and Wear Archives, DX.20/12. 
relied upon the nature of aerial theatre as a technological sublime, attractive because of its dangerous spectacle, its mixture of fun and fear. That its militaristic and violent spectacles were so eagerly consumed by so many people hints at the complex nature of the public understanding of the relationship between war, technology and modernity in Britain at a time when pacifist and internationalist feeling was at its height. That the RAF found it easier to show the effects of bombing on its imperial subjects rather than the white working class should not blind us to the messages that audiences found easy to read. In looking again at-and through—the air displays, races, flypasts and expeditions conducted by aviators and air forces around the world, aerial theatre can help us to see the world the aeroplane made, and threatened to destroy. 